\title{
EDITORIAL
}

\section{Current status and advances in corrosion researches}

\author{
Su-II Pyun • Sung-Jai Lee
}

Received: 13 February 2009 / Accepted: 13 February 2009/Published online: 10 March 2009

(C) Springer-Verlag 2009

Corrosion intrudes itself into many parts of our lives, e.g., household appliances, electric power generating plants, airplanes, and automobiles. Many have spent hundreds of dollars on aftermarket corrosion protection systems for new products to delay the dreaded rust appearance [1]. Therefore, the need for corrosion research is based industrially as well as scientifically.

In order to find the protection methods from corrosion, it is first necessary to elucidate corrosion mechanism. For several decades, alternating current (AC) impedance spectroscopy has been developed for studying corrosion mechanism. Among various methods for elucidating corrosion mechanism, AC impedance spectroscopy is the most favorable electrochemical technique since it can provide a quantitative measurement for corrosion [2]. Many researchers have been studying the degradation mechanism of such materials as pure metals, metal alloys, and surface-coated specimens using AC impedance spectroscopy [2-8].

In more recent years, the problem of linearization of electrochemical processes and the possibility of realization of impedance measurements in non-linear conditions have been discussed [9]. For the impedance measurements to be more reliable, a new experimental technique, i.e., dynamic electrochemical impedance spectroscopy (DEIS) was developed [10-12]. Classical impedance spectroscopy can provide information concerning only before and after the corrosion process. In this technique, however, since the electrode impedance is measured continuously in potentiodynamic conditions, DEIS allows to investigate the proceeding corrosion process in time. Hence, one can obtain

S.-I. Pyun $(\bowtie) \cdot$ S.-J. Lee

Korea Advanced Institute of Science and Technology,

Daejeon, Republic of Korea

e-mail: sipyun@kaist.ac.kr very detailed characteristic of the examined corrosion system.

In addition, it has been reported that some corrosions such as pitting corrosion are regarded as a stochastic process at the native oxide films. Since the fluctuations in potential or current associated with the pitting process can be easily observed in the experimental data, electrochemical noise measurement has been newly used for monitoring as well as studying corrosion processes. Many researchers have investigated the pitting corrosion in terms of the statistical variation in the pitting potential and pit embryo density [13-16]. In addition, the pitting corrosion has been described with fractal geometry [17-19].

From now on, some of the protection methods from corrosion will be briefly introduced. In general, the corrosion protections can be classified methodologically into three methods: (1) addition of corrosion inhibitor, (2) formation of protective film by coating, and (3) material design.

First, the preventing methods by adding corrosion inhibitors were explained. In general, inhibitor means the chemical compounds that deposit on exposed material surfaces from the corrosive environment. The inhibitor may form either a uniform film-like coating which acts as a physical barrier or a few monolayers which alter the electrochemical reactivity of the surface to reduce the corrosion rate. In the literatures, the reduction in corrosion rate has been presented by adding metallic inhibitor [20-24] and non-metallic inhibitor [25-31]. Recently, environmentally friendly inhibitors have been widely investigated [32, 33].

Second, the corrosion protections by coating have been presented in corrosion researches. The major advantage of coating is that coatings can preserve the material appearance, which is often a major concern for structures and equipment routinely exposed to public view. There are two kinds of coatings, i.e., organic coating and metallic coating. 
Organic coatings act primarily as a physical barrier between the substrate and the corrosive environment. Metallic coatings also act as a corrosion-resistant physical barrier and, at the same time, provide sacrificial cathodic protection to exposed adjacent areas of a metal substrate of dissimilar composition. There are many literatures concerning the corrosion protection methods by introducing organic coating [34-38] and metallic coating [39-48].

Finally, the corrosion protections were investigated as a function of material composition. Indeed, the most effective method of corrosion prevention is the proper selection of materials resistant to the specific corrosive environment. Hence, the alloy systems comprise the great majority of materials used in engineering applications. Many literatures dealing with the variation of corrosion resistance by compositional change has been published in the field of corrosion research [49-56].

As the above examples show, there is a broad and rapidly increasing range of corrosion researches focusing on the protection methods and we are looking forward to the future progress in corrosion researches. In this report, of course, we can only touch on the limited aspects of the wide area concerning the corrosion mechanism and corrosion protection of corrosion researches. On our personal note, we have learned a lot and even managed to have fun in DEIS technique, fractal theory, and green inhibitor during editing this journal. We hope that everyone might receive the same pleasure and be similarly inspired.

\section{References}

1. Jones DA (1996) Principles and prevention of corrosion. Prentice Hall, Upper Saddle River, $p 1$

2. Lee SJ, Pyun SI (2007) J Solid State Electrochem 11:829

3. Baril G, Galicia G, Deslouis C, Pebere N, Tribollet B, Vivier V (2007) J Electrochem Soc 154:C108

4. Chen J, Wang JQ, Han EH, Dong JH, Ke W (2007) Electrochim Acta 52:3299

5. Muñoz AG, Chen Q, Schmuki P (2007) J Solid State Electrochem 11:1077

6. Marín-Cruz J, Cabrera-Sierra R, Pech-Canul MA, González I (2007) J Solid State Electrochem 11:1245

7. Hamlaoui Y, Pedraza F, Tifouti L (2008) Corros Sci 50:1558

8. Mendoza-Canales J, Marín-Cruz J (2008) J Solid State Electrochem 12:1637

9. Darowicki K (2000) J Electroanal Chem 486:101

10. Darowicki K, Kawula J (2007) Russ J Electrochem 43:1055

11. Hassanzadeh A (2007) Corros Sci 49:1895

12. Nagarajan S, Karthega M, Rajendran N (2007) J Appl Electrochem 37:195

13. Cafissi A, Invernizzi AJ, Trasatti SP (2007) Corros Rev 25:233

14. Darowicki K, Zieliński A (2007) J Solid State Electrochem 11:109

15. Na KH, Pyun SI (2007) Electrochim Acta 52:4363

16. Itagaki M, Shitanda I, Nakajma D, Watanabe K, Hirasaki T, Nukaga T, Umemura F (2008) Electrochemistry 76:471

17. Park JJ, Pyun SI (2003) J Solid State Electrochem 7:380

18. Pyun SI, Park JJ (2004) J Solid State Electrochem 8:296
19. Go JY, Pyun SI (2007) J Solid State Electrochem 11:323

20. Paliwoda-Porebska G, Rohwerder M, Stratmann M, Rammelt U, Duc LM, Plieth W (2006) J Solid State Electrochem 10:730

21. Arancibia A, Henriquez-Roman J, Paez MA, Padilla-Campos L, Zagal JH, Costamagna J, Cardenas-Jiron G (2007) J Solid State Electrochem 10:894

22. Kendig M, Kinlen P (2007) J Electrochem Soc 154:C195

23. Babić-Samardžija K, Hackerman N, Sovilj SP, Jovanović VM (2008) J Solid State Electrochem 12:155

24. Ashraf PM, Shibli SMA (2008) J Solid State Electrochem 12:315

25. Survila A, Bražinskienė D (2007) J Solid State Electrochem 11:65

26. Villamizar W, Casales M, Gonzalez-Rodriguez JG, Martinez L (2007) J Solid State Electrochem 11:619

27. Vrsalovic L, Kliskic M, Radosevic J, Gudic S (2007) J Appl Electrochem 37:325

28. Khaled KF (2008) Mat Chem Phys 112:104

29. Villamizar W, Casales M, Martinez L, Chacon-Naca JG, Gonzalez-Rodriguez JG (2008) J Solid State Electrochem 12:193

30. Oguzie EE, Wang SG, Li Y, Wang FH (2008) J Solid State Electrochem 12:721

31. Özcan M (2008) J Solid State Electrochem 12:1653

32. Avdeev YG, Belinskii PA, Kuznetsov YI, Zell OO (2007) Prot Met 43:587

33. Ismail KA (2007) Electrochim Acta 52:7811

34. Mondal S, Munichandraiah N (2006) J Solid State Electrochem 10:78

35. Ohtsuka T, Iida M, Ueda M (2006) J Solid State Electrochem 10:714

36. Sathiyanarayanan S, Azim SS, Venkatachari G (2007) Electrochim Acta 52:2068

37. Sathiyanarayanan S, Azim SS, Venkatachari G (2008) J Appl Polym Sci 107:2224

38. Skale S, Dolecek V, Slemnik M (2008) Prog Org Coat 62:387

39. Penney DJ, Sullivan JH, Worsley DA (2007) Corros Sci 49:1321

40. Schmidt DP, Shaw BA, Sikora E, Shaw WW, Laliberte LH (2007) Corrosion 63:958

41. Shibli SMA, Dilimon VS, Saji VS (2007) J Solid State Electrochem 11:201

42. Arsova I, Arsov L, Hebestreit N, Anders A, Plieth W (2007) J Solid State Electrochem 11:209

43. Prusi A, Arsov L (2007) J Solid State Electrochem 11:355

44. Hu F, Chan KC, Song SZ, Yang XJ (2007) J Solid State Electrochem 11:745

45. Georgieva J, Armyanov S (2007) J Solid State Electrochem 11:869

46. Li MC, Jiang Li Li, Zhang WQ, Qian YH, Luo SZ, Shen JN (2007) J Solid State Electrochem 11:1319

47. Noskov AV, Grishina EP (2008) J Solid State Electrochem 12:203

48. Chang JK, Chen SY, Tsaia WT, Deng MJ, Sun IW (2008) J Electrochem Soc 155:C112

49. Gonzalez-Rodriguez JG, Rosales I, Lopez SY, Guardian R (2007) J Solid State Electrochem 11:478-481

50. Osório WR, Cheung N, Spinelli JE, Goulart PR, Garcia A (2007) J Solid State Electrochem 11:1421

51. Amokrane S, Ladjouzi MA (2007) J Solid State Electrochem 11:1655

52. Bastos MC, Proença LFA, Neto MMM, Fonseca ITE (2008) J Solid State Electrochem 12:121

53. Gonzalez-Rodriguez JG, Gonzalez-Castañeda M, Cuellar-Hernández M, Domínguez-Patiño G, Rosas G (2008) J Solid State Electrochem 12:707

54. Królikowski A, Płońska E, Ostrowski A, Donten M, Stojek Z (2009) J Solid State Electrochem 13:263

55. Byk TV, Gaevskaya TV, Tsybulskaya LS (2008) Surf Coat Tech 202:5817

56. Montemor MF, Simoes AM, Ferreira MGS, Carmezim MJ (2008) Appl Surf Sci 254:1806 